\title{
Detección de la expresión génica in vivo de Mycobacterium tuberculosis durante la tuberculosis pulmonar activa
}

\author{
ALEJANDRA OTAZO M.*, INGRID GUTIÉRREZ S.**, VÍCTOR ACEVEDO F.***, \\ CARLOS CALDERÓN A.**** y NANCY P. MAULÉN L.*****,******
}

\section{Mycobacterium tuberculosis in vivo-expressed genes detection during active pulmonary tuberculosis}

Mycobacterium tuberculosis gene expression studies have involved "in vitro", "ex vivo" and "in vivo" experiments (animal models), but without the expected success. We propose that key features of human tuberculosis could be discovered by studying the M. tuberculosis gene expression within the human host. Therefore, we isolated total M. tuberculosis $m R N A$ from human clinical respiratory specimens of patients diagnosed with pulmonary tuberculosis; after this, we synthesized the dscDNA and tested it by qualitative RT-PCR assays. We detected the expression of IS6110 insertion sequence and of the "housekeeping" genes 16SrRNA and sigA in M. tuberculosis grown in vivo (pulmonary tuberculosis) as well as grown in vitro M. tuberculosis. mprA and mprB genes expression, which code the MprAB signal transduction system, were only detected in M. tuberculosis grown in vitro. Our results provide the first step towards a non invasive method for the study of the transcriptome of M. tuberculosis within its native host, to analyze "in vivo" regulation of the genetic determinants required for virulence and pathogenesis.

Key words: Mycobacterium tuberculosis; in vivo expression; mRNA; pulmonary tuberculosis.

\section{Resumen}

El estudio de la expresión génica de Mycobacterium tuberculosis ha involucrado la experimentación "in vitro", "ex vivo" e "in vivo" (modelos animales), pero aún sin el éxito esperado. Proponemos que revelar los factores clave de la tuberculosis humana requiere investigar la expresión génica de M. tuberculosis dentro del ser humano ("in vivo"). Para ello, aislamos el mRNA total de M. tuberculosis, desde muestras clínicas respiratorias de pacientes con diagnóstico de tuberculosis pulmonar; posteriormente, sintetizamos el dscDNA y lo analizamos mediante RT-PCR cualitativo. Detectamos la expresión de la secuencia de inserción IS6110 y de los genes "housekeeping" 16SrRNA y sigA en M. tuberculosis creciendo in vivo (tuberculosis pulmonar) así como cultivado in vitro. La expresión de los genes mprA y mprB, que codifican el sistema de transducción de señales MprAB, sólo se detectó en M. tuberculosis crecido in vitro. Con nuestros resultados damos el primer paso hacia la implementación de un método no invasivo para el estudio del transcriptoma de M. tuberculosis, dentro de su único hospedero natural, con el fin de analizar la regulación "in vivo" de los determinantes genéticos requeridos para su virulencia y patogénesis.

Palabras clave: Mycobacterium tuberculosis; expresión in vivo; $m R N A$; tuberculosis pulmonar.

Financiamiento: Este trabajo fue financiado mediante proyecto regular FONDECYT 1040978, de Chile.

\footnotetext{
* $\quad$ Enfermera, Hospital Penitenciario "El Manzano”, Gendarmería de Chile, Concepción, Chile.

** Tecnólogo Médico. Jefe Laboratorio de Tuberculosis, Servicio de Salud Concepción, Concepción, Chile.

*** Médico, Jefe Programa de Control de la Tuberculosis, Secretaría Ministerial de Salud, Concepción, Chile.

**** Estudiante carrera Bioquímica, Pontificia Universidad Católica de Valparaíso, Curauma, Chile.

***** Bioquímico, Doctora en Ciencias, Facultad de Medicina y Biociencias, Universidad San Sebastián, Santiago, Chile.

****** Directora carrera Ingeniería en Biotecnología. Universidad Andrés Bello. Viña del Mar.
} 


\section{Introducción}

La tuberculosis, causada por Mycobacterium tuberculosis, continúa siendo la primera causa de muerte debido a una infección por un agente microbiano ${ }^{1-3}$. Para el control, la prevención y la erradicación de la tuberculosis se necesita conocer con urgencia la biología y la patogénesis de M. tuberculosis, así como las manifestaciones clínicas asociadas a cada etapa de la infección ${ }^{4-6}$.

Sin embargo, el estudio de la expresión génica de M. tuberculosis se ha limitado a sistemas de cultivo celular y modelos animales, dónde no se reproduce a cabalidad las características clave de la tuberculosis humana. A consecuencia de ello, existe mínima información en el contexto de la infección humana, es decir, durante el crecimiento in vivo del bacilo ${ }^{7,8}$. Para, descubrir aquellos genes que $M$. tuberculosis expresa cuando se replica dentro del ser humano ${ }^{7-9}$, nos propusimos detectar el mRNA del bacilo en muestras clínicas respiratorias humanas obtenidas desde pacientes con tuberculosis pulmonar activa y de pacientes sin confirmación diagnóstica. Para ello, decidimos comenzar estudiando la expresión de la secuencia de inserción $I S 6110$ y de los genes $16 \operatorname{SrRNA}$, sigA, mprA and $m p r B$ en muestras de esputo y lavado broncoalveolar. IS6110 es específica de los miembros del complejo $M$. tuberculosis $^{10,11} ; 16 \operatorname{Sr} R N A$ y sigA cumplen funciones "housekeeping"7,11. El sistema de dos componentes $\mathrm{Mpr} A \mathrm{~B}$, asociado a virulencia in vivo e in vitro, se induce al interior de los macrófagos humanos ${ }^{9,12,13}$ y es esencial para el crecimiento in vivo del bacilo en un modelo de infección latente.

Presentamos evidencia que demuestra la detección del mRNA de $M$. tuberculosis en muestras de esputo de pacientes con tuberculosis pulmonar activa (expresión in vivo), siendo capaces de identificar la expresión de $I S 6110$ y de los genes $16 S r R N A$ y $\operatorname{sig} A$. Los genes $m p r A$ y $m p r B$ sólo se detectaron en $M$. tuberculosis crecido in vitro. Con nuestros resultados damos el primer paso hacia la implementación de un método no invasivo para el estudio del transcriptoma de $M$. tuberculosis, dentro de su reservorio natural, el ser humano, con el fin de analizar la regulación in vivo de los determinantes genéticos requeridos para su virulencia y patogénesis.

\section{Materiales y Métodos}

Cepas y DNAs de Mycobacterium: Se trabajó con DNAs aislados de M. tuberculosis H37Rv (ATCC $\mathrm{N}^{\circ}$ 27294), M. tuberculosis var. bovis BCG Pasteur (ATCC No 27291), M. smegmatis
(ATCC $\mathrm{N}^{\circ}$ 700084) y M. marinum (ATCC $\mathrm{N}^{\circ}$ 15.069). La cepa M. tuberculosis H37Rv cultivada in vitro fue adquirida en el Instituto de Salud Pública de Chile (ISP). Como DNA control se utilizó DNA genómico de Helicobacter pylori TN5 aislada por el Dr. Guillermo Figueroa de la Universidad de Chile, Santiago, Chile.

\section{Cultivo microbiológico y baciloscopia (BK)}

El cultivo microbiológico de M. tuberculosis se realizó en medio Löwenstein-Jensen (L-J). Para el aislamiento de DNA y RNA de $M$. $t u$ berculosis éste se cultivó sin agitación por 4 a 6 semanas a $37^{\circ} \mathrm{C}$. Los frotis de las muestras de esputo y lavado broncoalveolar (LBA) para microscopía óptica se sometieron a tinción ZiehlNeelsen (Baciloscopia-BK); ambas técnicas se llevaron a cabo en el Laboratorio de Tuberculosis del Servicio de Salud Concepción, siguiendo las recomendaciones de la Organización Panamericana de la Salud (OPS) ${ }^{14}$.

\section{Selección de pacientes y muestras clínicas pulmonares}

La selección de los pacientes se hizo considerando la presencia de síntomas clínicos que hicieran sospechar el diagnóstico de tuberculosis pulmonar. Las muestras se obtuvieron antes de iniciar la terapia antituberculosa, durante un período de dos años de recolección, y luego de la obtención del consentimiento informado de pacientes VIH-negativos con diagnóstico de tuberculosis pulmonar por radiografía de tórax, baciloscopia (BK) positiva y/o cultivo positivo. También, se incluyó muestras de LBA de pacientes sin confirmación diagnóstica de tuberculosis pulmonar, es decir, BK y cultivo negativos. Se seleccionó un total de 24 pacientes hombres mayores de 18 años, residentes del Centro de Reclusión Penitenciaria "El Manzano", de la VII Región del Bío-Bío, Chile; Se recolectó 24 muestras clínicas (una por paciente): Esputo $(n=21)$ y lavado broncoaleolar $(\mathrm{LAB})(\mathrm{n}=3)$. De una porción pequeña de cada muestra se extrajo el DNA total y todo lo restante de la muestra fue inmediatamente conservado en RNA Later (Ambion), según las instrucciones del fabricante. Posteriormente, se construyó al azar tres "pools" de muestras de esputo positivas (BK y/o cultivo positivas), incluyendo distinto número de muestras en cada uno de ellos, para realizar la extracción de RNA total: Pool A $(\mathrm{n}=9)$, pool $\mathbf{B}(\mathrm{n}=4)$ y pool $\mathbf{C}(\mathrm{n}=8)$. Por otra parte, todas las muestras de LBA negativas se utilizaron para construir el pool $\mathbf{D}(\mathrm{n}=3)$. El pool $\mathbf{E}$ corresponde a una colonia de $M$. tuberculosis cultivado in vitro. En todo momento las muestras se manipularon con nivel de bioseguridad 2 . 


\section{Aislamiento de DNA desde cultivo microbiológico (in vitro) y muestras clínicas pulmonares (in vivo)}

Se extrajo el DNA total de una colonia de $M$. tuberculosis, desde las muestras de esputo y de los LBA de los pacientes, utilizando un método forense ${ }^{15,16}$. Brevemente, el pellet se resuspendió en 100-300 $\mu \mathrm{l}$ de $20 \%$ Quelex-100 ${ }^{\mathrm{TM}}$, se incubó $30 \mathrm{~min}$ a $56{ }^{\circ} \mathrm{C}$ y luego por $10 \mathrm{~min}$ a $95{ }^{\circ} \mathrm{C}$. El sobrenadante que contiene al DNA se almacenó $\mathrm{a}-20^{\circ} \mathrm{C}$.

\section{Determinación de la especificidad del PCR de tiempo real para IS6110 y límite de detección}

La pareja de partidores I (Tabla 1), previamente reportada, amplifica una región conservada de 163 -pb de $I S 6110^{17}$. La mezcla de reacción utiliza $4.5 \mathrm{mM} \mathrm{Mg}^{+2}$ y 10 pmol de cada partidor ; $2 \mu \mathrm{lde}$ DNA se agregan sobre $18 \mu \mathrm{l}$ de Master Mix DNA SybrGreenÔ, sometiéndose a amplificación según las siguientes condiciones, en un equipo LightCyclerÔ Thermocycler (Roche): desnaturación a 95 ${ }^{\circ} \mathrm{C}$ por $5 \mathrm{~m}, \mathrm{y} 45$ ciclos de $95{ }^{\circ} \mathrm{C}$ por $5 \mathrm{~s}, 68-65^{\circ} \mathrm{C}$ por $5 \mathrm{~s} \mathrm{y} 72{ }^{\circ} \mathrm{C}$ por $7 \mathrm{~s}$. Las reacciones de PCR se realizaron para cada muestra en duplicado en distintos días. Para demostrar la especificidad de la secuencia de inserción IS6110, se analizó 50 ng de DNA de $M$. tuberculosis, $M$. bovis BCG, M. smegmatis, $M$. marinum y H. pylori TN5. H. pylori se usó como control, porque es una infección altamente prevalente del tubo digestivo, la cual en Sudamérica, afecta entre 70 a $90 \%$ de la población. Para establecer el rango de linealidad se construyó una curva de calibración en el rango $\left[1 \times 10^{-3}\right.$ a $\left.1 \times 10^{3} \mathrm{pg}\right]$, utilizando como estándar el amplicón IS6110 (purificado y cuantificado). Para establecer la sensibilidad se realizó dilu- ciones seriadas de $M$. tuberculosis H37Rv DNA (ATCC), en el rango [ $1 \times 10^{0}$ a $1 \times 10^{5}$ bacilos], las cuales se amplificaron bajo los parámetros citados. Tres concentraciones de DNA conocidas se amplificaron en tres días distintos.

\section{Ensayos de PCR de tiempo real para la detección de IS6110 y los genes 16SrRNA, sigA, mpr A y mprB utilizando dscDNA sintetizado como templado}

La amplificación de IS6110 se realizó en base a los parámetros previamente citados. La inhibición de la PCR se descartó utilizando DNA de M. tuberculosis como control interno de amplificación. La pareja de partidores M (Tabla 1), amplifica una región de 416-pb del gen 16SrRNA. La mezcla de reacción utiliza $3 \mathrm{mM} \mathrm{Mg}^{+2}$ y 10 pmol de cada primer; $2 \mu \mathrm{l}$ de DNA se agregan sobre $18 \mu \mathrm{l}$ de Master Mix DNA SybrGreenÔ. Las condiciones de amplificación (LightCyclerÔ Thermocycler-Roche) son: desnaturación a $95^{\circ} \mathrm{C}$ por $5 \mathrm{~m}, \mathrm{y} 45$ ciclos de $95{ }^{\circ} \mathrm{C}$ por $5 \mathrm{~s}, 63-60^{\circ} \mathrm{C}$ por $5 \mathrm{~s} \mathrm{y} 72{ }^{\circ} \mathrm{C}$ por $10 \mathrm{~s}$. Para la amplificación de sigA se utiliza los partidores H (Tabla 1), $4 \mathrm{mM}$ $\mathrm{Mg}^{+2}$ y 10 pmol de cada primer. Las condiciones de amplificación son: desnaturación a $95{ }^{\circ} \mathrm{C}$ por $5 \mathrm{~m}$, y 45 ciclos de $95^{\circ} \mathrm{C}$ por $5 \mathrm{~s}, 63-60{ }^{\circ} \mathrm{C}$ por 5 s y $72{ }^{\circ} \mathrm{C}$ por $7 \mathrm{~s}$. Para amplificar los genes mpr $A$ y $m p r B, 4 \mathrm{mM} \mathrm{Mg}^{+2}$ y 10 pmol de la pareja de primers A y B, respectivamente (Tabla 1). Las condiciones de amplificación para ambos son las mismas: desnaturación a $95^{\circ} \mathrm{C}$ por $5 \mathrm{~min}$, y 45 ciclos de $95^{\circ} \mathrm{C}$ por $5 \mathrm{~s}, 59^{\circ} \mathrm{C}$ por $5 \mathrm{~s} \mathrm{y} 72{ }^{\circ} \mathrm{C}$ por $7 \mathrm{~s}$. En todos los casos la fluorescencia se detectó durante la fase de extensión, y el análisis de PCR de cada dscDNA, correspondiente a los pools $\mathbf{A}$, $\mathbf{B}, \mathbf{C}, \mathrm{D}$ o $\mathbf{E}$; se efectuó en dos reacciones sepa-

Tabla 1. Parejas de partidores utilizados para las reacciones de amplificación en PCR (reacción de polimerasa en cadena) de tiempo-real

\begin{tabular}{|c|c|c|c|c|}
\hline $\operatorname{Par} \mathbf{N}^{\circ}$ & Secuencia blanco & Secuencia partidor & $\begin{array}{l}\text { GenBank } \\
\text { ID }\end{array}$ & $\begin{array}{l}\text { Amplicón } \\
\text { Tamaño (bp) }\end{array}$ \\
\hline A & mprA & $\begin{array}{l}\text { 5'-CATTGCTGGAGATGCCTGATCG-3' } \\
\text { 5'-CTCGGTCTTGCGGCGTAG-3' }\end{array}$ & 885038 & 100 \\
\hline B & $m p r B$ & $\begin{array}{l}\text { 5'-ATCCGTGGCGAGTTGTTC-3', } \\
\text { 5'-CTTCGGTGGGCTTGAGAC-3', }\end{array}$ & 885062 & 100 \\
\hline $\mathrm{C}$ & IS6110 & $\begin{array}{l}\text { 5'-GGCTGTGGGTAGCAGACC-3', } \\
\text { 5'-CGGGTCCAGATGGCTTGC-3'. }\end{array}$ & X52471 & 163 \\
\hline M & $16 \operatorname{Sr} R N A$ & $\begin{array}{l}\text { 5'-GCTTTAGCGTGGGATGAGCC-3' } \\
\text { 5'-GCGACGCTCACAGTTAAGCCGTG-3' }\end{array}$ & X52917 & 416 \\
\hline $\mathrm{H}$ & $\operatorname{sig} A$ & $\begin{array}{l}\text { 5'-GCCGATGACGACGAGGAG-3' } \\
\text { 5'-GGCGGATGCGGTGAGTTC-3' }\end{array}$ & 887477 & 100 \\
\hline
\end{tabular}


radas con el fin de determinar la reproducibilidad del ensayo.

\section{Aislamiento de RNA total desde \\ $M$. tuberculosis crecido in vitro (cultivado en medio L-J) $e$ in vivo (muestras clínicas pulmonares)}

Para aislar el mRNA total bacteriano se procesó, por una parte, una colonia de M. tuberculosis (pool E) y por la otra, los pools de muestras pulmonares $\mathbf{A}, \mathbf{B}, \mathbf{C}$ y $\mathbf{D}$, en forma independiente. Todos los pools fueron conservados en RNALater (Ambion) a $-70^{\circ} \mathrm{C}$. Brevemente, una colonia de M. tuberculosis y $\sim 5 \mathrm{ml}$ de cada pool de muestra se procesó con el kit RiboPure-Bacteria (Ambion), el cual combina la ruptura de la pared bacteriana, llevada a cabo con esferas de Zirconia, con la extracción fenólica del lisado, seguido de la purificación del RNA mediante filtro de fibra de vidrio. Post-elución se removió el DNA contaminante con el reactivo DNA-free (Ambión). La concentración de RNA total libre de DNA se determinó mediante $\mathrm{A}_{260 \mathrm{~nm}}$. Los pools de RNA total se almacenaron $\mathrm{a}-70{ }^{\circ} \mathrm{C}$ hasta su utilización.

\section{Síntesis de dscDNA utilizando RNA total bacteriano como templado}

Se usó $800 \mathrm{ng}$ de cada pool de RNA total bacteriano de alta pureza para sintetizar el correspondiente dscDNA utilizando el kit MessageAmp II-Bacteria kit (Ambion). Para evaluar la calidad de cada extracción se analizó la expresión de IS6110, $16 \operatorname{SrRNA}$ y $\operatorname{sig} A$ utilizando a cada pool de dscDNA como templado para la reacción de amplificación por PCR de tiempo real.

\section{Implicancias éticas}

El comité de ética de la Universidad Andrés Bello, sede Viña del Mar, y del Programa de Control de la Tuberculosis de la región del Bío-Bío, aprobaron todos los protocolos de investigación. De todos los pacientes incluídos en el estudio se obtuvo el consentimiento informado para el análisis de sus muestras clínicas.

\section{Resultados}

\section{Detección específica del genoma de Mycobacterium tuberculosis en las muestras clínicas pulmonares de pacientes con tuberculosis pulmonar activa}

Se determinó que el rango de linealidad del ensayo de PCR de tiempo real para IS6110 es de $\left[1 \times 10^{-3}\right.$ a $\left.1 \times 10^{3} \mathrm{pg}\right]$ y la sensibilidad de $50 \mathrm{fg} /$ $\mathrm{ml}$ de DNA genómico equivalentes a 10 bacilos (Figura 1-A). El DNA de M. tuberculosis H37Rv o de $M$. bovis BCG, pero no de $M$. smegmatis o M. marinum, resultó en la generación de un solo producto de amplificación de 163-pb. Asimismo, no se observó amplificación a partir del DNA de H. pylori (Figura 1-B, Figura 1-C). De las 24 muestras clínicas incluidas en la presente investigación, en el $100 \%$ de las muestras de esputo

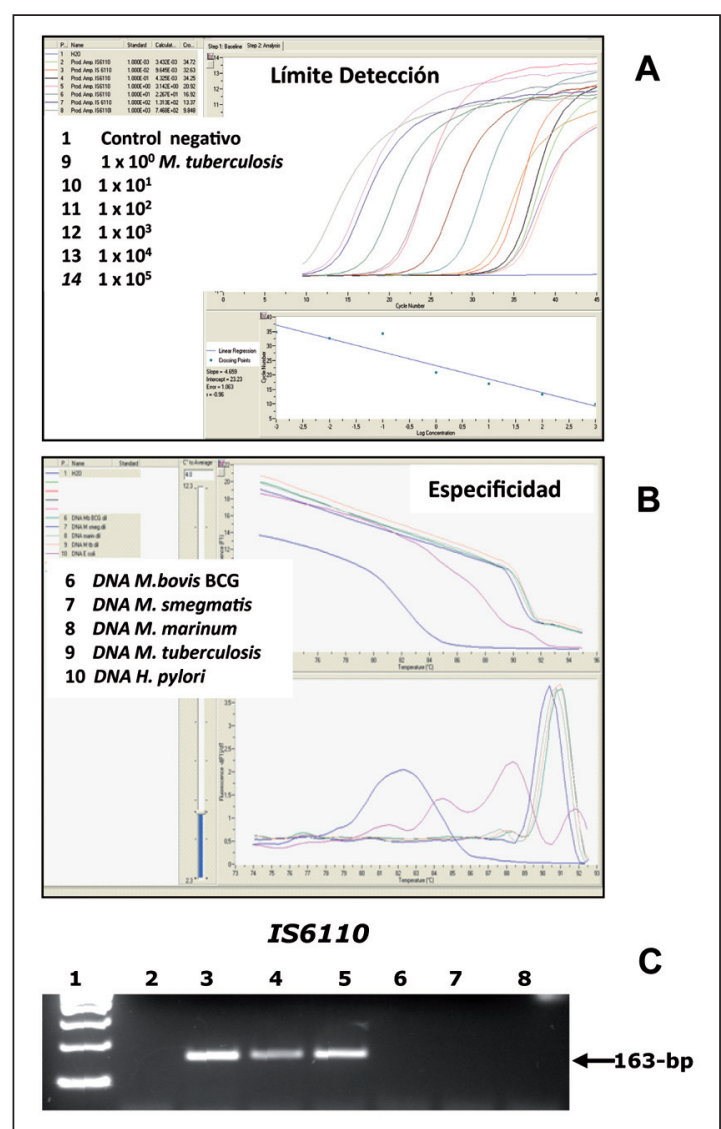

Figura 1. Límite de detección y especificidad de la secuencia de inserción IS6110 del complejo Mycobacterium tuberculosis. (A) El gráfico muestra la utilización del producto de amplificación IS6110 (163-pb) como estándar de DNA para construir una curva de calibración en el rango [1 x $10^{-3}$ a $1 \times 10^{3} \mathrm{pg}$ ]. Capilar: (1) Control negativo; (2) a (8) Diluciones seriadas del producto de PCR (163-pb) cuantificado y equivalente a distintas cantidades de bacilo, rango [1 x $10^{0}$ a $1 \times 10^{5}$ bacilos]. (B) El gráfico muestra la especificidad del ensayo utilizando como templado $50 \mathrm{ng}$ de DNA genómico de $M$. bovis BCG (capilar 6); DNA M. smegmatis (capilar 7); DNA M. marinum (capilar 8); DNA M. tuberculosis H37Rv (capilar 9) y DNA H. pylori (capilar 10). Los productos de PCR presentaron valores de $\mathrm{T}^{\circ}$ fusión de $\left[91 \pm 1^{\circ} \mathrm{C}\right]$. (C) Correspondiente electroforesis en gel de agarosa al $2 \%$ indicando el producto de PCR de 163-pb único y específico generado con la pareja de partidores C. Carriles: 1) Estándar MW, ladder de 100-pb; 2) Control negativo; El DNA se reemplazó por agua. 3) DNA $M$. tuberculosis H37Rv (ISP); 4) DNA DNA $M$. bovis BCG; 5) DNA $M$. tuberculosis H37Rv (ATCC); 6) DNA M. smegmatis; 7) DNA M. marinum; 8) DNA H. pylori. 
$(\mathrm{n}=21)$ BK y/o cultivo positivas se detectó la secuencia de inserción IS6110, específica del complejo M. tuberculosis. Dicho resultado confirma la presencia del genoma de $M$. tuberculosis en cada pool de muestras pulmonares. Por otro lado, en concordancia con los reportes del Laboratorio de Tuberculosis del Hospital, el pool D, correspondiente a muestras de LBA de pacientes sin confirmación diagnóstica (tuberculosis pulmonar activa), también resultaron negativas para la presencia de DNA correspondiente a la secuencia de inserción IS6110 (datos no mostrados). El pool (E), correspondiente a $M$. tuberculosis crecido in vitro, resultó positivó para IS6110.

\section{Detección de la expresión de la secuencia de inserción IS6110 y de los genes constitutivos sig A y 16SrRNA de M. tuberculosis en pacientes con tuberculosis pulmonar activa} (in vivo) y en M. tuberculosis crecido in vitro

El RNA total extraído de cada pool fue sometido a control de calidad antes de comenzar con la síntesis de los pools de dscDNA respectivos, utilizando IS6110 como blanco de amplificación (Figura 2-A), debido a que ésta es específica y única del complejo $M$. tuberculosis y generalmente se encuentra en varias copias en el genoma de aislados clínicos de M. tuberculosis. Luego, del tratamiento de cada pool de dscDNA con DNAasa, se repitió la amplificación de $I S 6110$, demostrándose la degradación completa del DNA contaminante (Figura 2-B). La amplificación de $I S 6110$ resultó negativa para el pool $\mathbf{D}$ (control negativo) y positiva para los pools dscDNA A, B y C, correspondientes a muestras pulmonares de pacientes con confirmación diagnóstica (BK y/o cultivo positivo). Asimismo, la amplificación de IS6110 resultó positiva para el pool $\mathbf{E}$, representativo del crecimiento in vitro de $M$. tuberculosis (Figura 2-C). La amplificación del gen $16 \operatorname{Sr} R N A$, el cual corresponde a un gen "housekeeping", que se expresa en alto número de copias, resultó positiva para los pools dscDNA A, B y E y negativa para los pools C y D (Figura 3-A). De igual manera, la expresión de $\operatorname{sig} A$, también un gen constitutivo, sólo se detectó en los pools A, B y E (Figura 3-B). Previamente, también se ha reportado la expresión constitutiva de los genes $16 \operatorname{Sr} R N A$ y $\operatorname{sig} A$ bajo una variedad de condiciones de crecimiento de M. tuberculosis ${ }^{9,12}$. Asimismo, corroboramos la expresión de los genes mprA y mprB en el pool $\mathbf{E}$, el cual representa a la condición fisiológica de crecimiento in vitro de $M$. tuberculosis en medio de cultivo L-J. No obstante, no se detectó amplificación de mprA y $m p r B$ en los pools $\mathbf{A}$, B y $\mathbf{C}$, que reflejan la condición de crecimiento in vivo

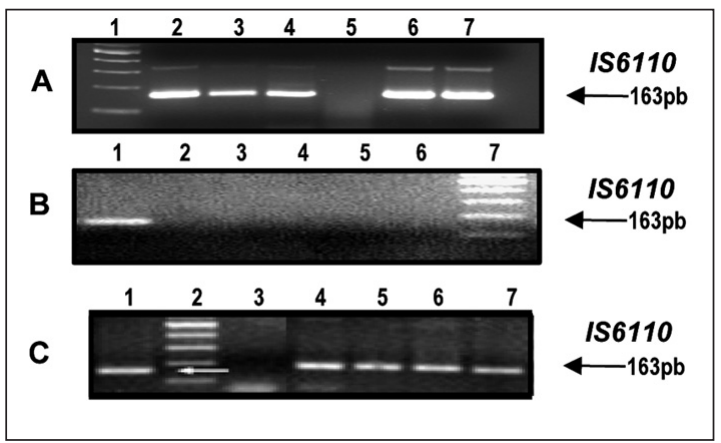

Figura 2. Análisis de calidad del RNA total extraído de cada pool de muestras utilizando IS6110 como blanco de amplificación. (A) Pools de RNA total como templado: Carriles: 1) Estándar MW, ladder 100-pb; 2) DNA $M$. tuberculosis (control positivo); 3) RNAt pool A; 4) RNAt pool B; 5) RNAt pool D; 6) RNAt pool C; 7) RNAt pool E. (B) Pools de RNA total tratados con DNAasa como templado: Carriles: 1) Estándar MW, ladder 100-pb; 2) DNA M. tuberculosis (control positivo); 3) RNAt pool A; 4) RNAt pool B; 5) RNAt pool D; 6) RNAt pool C; 7) RNAt pool E. (C) Pools de dscDNA sintetizados como templado: Carriles: 1) DNA M. tuberculosis (control positivo); 2) Estándar MW, ladder 100-pb; 3) RNAt pool D; 4) RNAt pool E; 5) RNAt pool A; 6) RNAt pool B; 7) RNAt pool C.

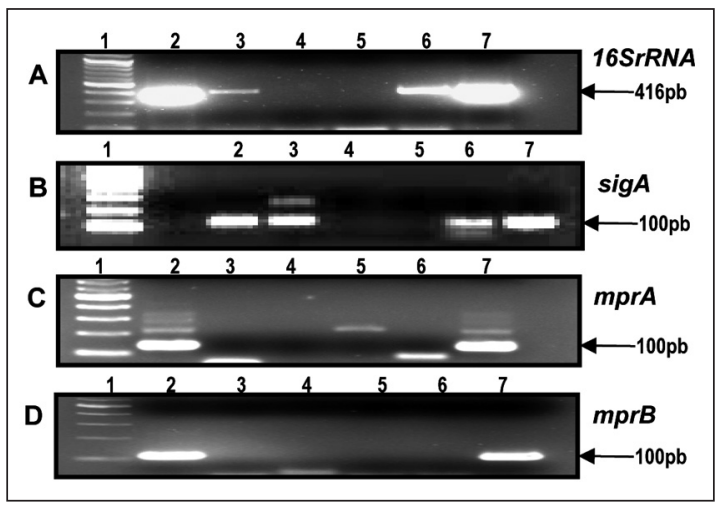

Figura 3. Productos de amplificación obtenidos mediante PCR de tiempo real utilizando los pools de dscDNA como templado y los partidores citados en la Tabla 1. (A) Gen 16SrRNA de M. tuberculosis como blanco de amplificación: Carriles: 1) Estándar MW, ladder 100-pb; 2) DNA M. tuberculosis (control positivo); 3) dscDNA pool A; 4) dscDNA pool D; 5) dscDNA pool C; 6) dscDNA pool B; 7) dscDNA pool E. (B) Gen $\operatorname{sig} A$ de M. tuberculosis como blanco de amplificación: Carriles: 1) Estándar MW, ladder 100-pb; 2) DNA M. tuberculosis (control positivo); 3) dscDNA pool A; 4) dscDNA pool D; 5) dscDNA pool C; 6) dscDNA pool B; 7) dscDNA pool E. (C) Gen mprA de M. tuberculosis como blanco de amplificación: Carriles: 1) Estándar MW, ladder 100-pb; 2) DNA M. tuberculosis (control positivo); 3) dscDNA pool A; 4) dscDNA pool D; 5) dscDNA pool C; 6) dscDNA pool B; 7) dscDNA pool E. (D) Gen $m p r B$ de M. tuberculosis como blanco de amplificación: Carriles: 1) Estándar MW, ladder 100-pb; 2) DNA M. tuberculosis (control positivo); 3) dscDNA pool A; 4) dscDNA pool D; 5) dscDNA pool C; 6) dscDNA pool B; 7) dscDNA pool E. 
Tabla 2. Resultados de las amplificaciones realizadas por PCR de tiempo-real utilizando los pools de dscDNA como templado y las cinco parejas de partidores citados en la Tabla 1

\begin{tabular}{|lcccccccc|}
\hline Muestra a amplificar & (n) & $\begin{array}{c}\text { Tipo crecimiento } \\
\text { M. tuberculosis }\end{array}$ & IS6110 & 16SrRNA & sigA & mprA & mprB \\
dscDNApool A & 9 & In vivo & $(+)$ & $(+)$ & $(+)$ & $(-)$ & $(-)$ \\
dscDNApool B & 4 & In vivo & $(+)$ & $(+)$ & $(+)$ & $(-)$ & $(-)$ \\
dscDNApool C & 8 & In vivo & $(+)$ & $(-)$ & $(-)$ & $(-)$ & $(-)$ & $(-)$ \\
dscDNApool D & 3 & In vivo & $(-)$ & $(-)$ & $(-)$ & $(-)$ & $(-)$ \\
dscDNApool E & 1 & In vitro & $(+)$ & $(+)$ & $(+)$ & $(+)$ & $(+)$ \\
\hline
\end{tabular}

(n): Número de muestras de esputo o LBA utilizadas para construir el pool A, B, C y D; En el caso de pool E corresponde a una colonia de $M$. tuberculosis.

de M. tuberculosis (tuberculosis activa) la cual es distinta al crecimiento in vivo en fase de latencia. Acorde a lo esperado, para el control negativo, tampoco hubo amplificación de $m p r A$ y $m p r B$ en el pool D (Figura 3; C-D). La Tabla 2 resume los resultados de amplificación obtenidos para cada pool de dscDNA.

\section{Discusión}

Hemos demostrado el aislamiento exitoso de mRNA de $M$. tuberculosis virulento en muestras clínicas pulmonares humanas. Consecuentemente, hemos logrado implementar una aproximación experimental alternativa para estudiar la tuberculosis pulmonar activa así como la regulación diferencial de los determinantes genéticos requeridos por $M$. tuberculosis para su virulencia y patogénesis. Similares aproximaciones experimentales han sido publicadas recientemente que demuestran que $M$. tuberculosis presenta una expresión génica diferencial (in vivo versus in vitro), la cual media la adaptación del patógeno al ambiente hostil que encuentra dentro de su hospedero, el ser humano ${ }^{18-20}$. También, se ha reportado el estudio del transcriptoma de $M$. tuberculosis en pools de cDNA preparados a partir de tejido pulmonar de ratón infectado ${ }^{21}$.

La detección de la expresión de la secuencia de inserción IS6110, durante la tuberculosis pulmonar activa, concuerda con la asociación reiterada de ésta a cepas virulentas de $M$. tuberculosis. De igual manera, se ha reportado que las cepas que presentan un mayor número de copias de IS6110 muestran también mayor grado de virulencia $^{22}$. Por lo mismo, durante años IS6110 se ha utilizado preferentemente para el estudio de la epidemiología molecular de la tuberculosis, a través de la obtención de la "huella genética" de aislados clínicos de $M$. tuberculosis obtenidos desde zonas geográficas que presentan brotes epidémicos importantes ${ }^{23}$. IS6110 es capaz de generar variación genotípica, que se traduce en una variación fenotípica especie específica, hecho que ha sido relacionado con la evolución de este patógeno, y con la adquisición de una ventaja selectiva que potencia su virulencia ${ }^{22}$.

Los genes $16 \operatorname{SrRNA}$ y $\operatorname{sig} A$ se expresan constitutivamente bajo una serie de condiciones fisiológicas ${ }^{8,9,24,25}$. Por ello, se esperaba detectar la presencia de ambos mRNAs, en cada uno de los pools de dscDNA que presentaron amplificación positiva para IS6110, es decir, aquellos pools donde la presencia del genoma $M$. tuberculosis había sido confirmada y donde además existía concordancia con los resultados de BK y/o cultivo positivos. Sin embargo, en uno de los pools de muestras de esputo no se detectó la expresión de los genes $\operatorname{sig} A$ y $16 S r R N A$. Ello, posiblemente a causa de la calidad de la muestra de esputo propiamente tal, la cual es difícil de procesar en forma homogénea y en ocasiones se obtiene muy contaminada. Esto, podría bajar el rendimiento de extracción del RNA total y aumentar la degradación del mismo, lo que sumado al hecho de que se está trabajando en el límite de detección de la técnica, explicaría que no se haya obtenido amplificación de éstos mRNAs, pero sí de la IS6110, el cual sabemos se encuentra en varias copias en el genoma de $M$. tuberculosis virulentos.

Por otro lado, debido a que la vida media del mRNA bacteriano es extremadamente corta, en comparación a la de su rRNA o DNA genómico, la detección del mRNA de IS6110, sigA y $16 S r$ $R N A$ en los pools de muestras de esputo, indica la presencia de $M$. tuberculosis vivos en replicación activa. Es decir, los genes IS6110, sigA y $16 S r R N A$ se expresan dentro de los pacientes con tuberculosis pulmonar activa, y por tanto, los 
pools de dscDNA que mostraron amplificación positiva para éstos, corresponden a material validado para el estudio de la condición fisiológica de crecimiento in vivo de M. tuberculosis.

La expresión de los genes mprA y $m p r B$ se detectó en $M$. tuberculosis crecido in vitro, lo cual concuerda con los hallazgos reportados previamente ${ }^{13}$. Por el contrario, no se detectó amplificación de mprA y $m p r B$ en los pools de muestras que representan la condición fisiológica de crecimiento in vivo de $M$. tuberculosis y a su vez tuberculosis activa y no latente. Es probable, que no hayamos detectado la expresión de ambos, al igual que de $16 \operatorname{Sr} R N A$ y $\operatorname{sig} A$, debido a la inestabilidad intrínseca de la molécula de mRNA, sumado al hecho de la baja cantidad del mRNA presente dentro de $M$. tuberculosis, ya que en este caso ambos genes son inducibles y de una copia ${ }^{9,13,26}$. No obstante, se esperaba que los genes mprA y mpr $B$, que codifican el sistema de dos componentes MprAB, requerido para el establecimiento de la tuberculosis latente, tanto in vivo como in vitro, no se expresaran durante la infección activa ${ }^{9,13,26,27}$. Sin embargo, no se puede concluir definitivamente al respecto hasta que realicemos los experimentos de amplificación de los mRNAs presentes en los pools de muestra y se analicen mediante PCR de tiempo real cuantitativo (qRT-PCR).

Consecuentemente, concluimos que los pools dscDNA A y B son los únicos con la calidad requerida para continuar con nuestra investigación. Posteriores experimentos son necesarios para optimizar nuestro método, ya que el estudio deberá continuar con el análisis de muestras individuales, con el fin de cuantificar la expresión relativa de los genes de interés, y en especial para definir el rol de MprAB durante la tuberculosis activa. Recientemente, se demostró que cuantificar la cantidad de mRNA presente en muestras de esputo de pacientes con tratamiento antituberculoso es una herramienta promisoria que permite monitorear el éxito del tratamiento ${ }^{28}$.

Nuestros resultados nos proveen del primer paso hacia un método no invasivo para el estudio del transcriptoma de $M$. tuberculosis dentro de su único hospedero natural conocido, el ser humano. Ello, nos permitirá investigar la regulación in vivo de los determinantes genéticos requeridos para la virulencia y patogénesis de $M$. tuberculosis. De hecho, recientemente se ha demostrado la expresión diferencial de los mRNAs de $M$. tuberculosis en primates ${ }^{20}$, en el pulmón de ratón versus el bacilo crecido in vitro, en el caso de genes asociados a la deprivación de hierro, a metabolismo alternativo del carbono e hipoxia celular ${ }^{8}$. Más aún, el mismo grupo de mRNAs, analizados en muestras de pulmón de pacientes sometidos a resección pulmonar por cirugía torácica, reveló que existen diferencias en la expresión de $M$. tuberculosis dentro de los seres humanos ${ }^{17,21}$. Es decir, se evidencian diferencias hospedero específicas entre el ambiente del tejido pulmonar humano versus el del ratón, lo cual sustenta la hipótesis de que la fisiología in vivo de M. tuberculosis variará de acuerdo a la especie de hospedero que infecte. Ello, indudablemente corrobora la importancia de estudiar la interacción patógeno-hospedero dentro del ser humano.

\section{Agradecimientos}

Agradecemos al Dr. Thomas C. Zahrt del Medical College de Wisconsin, Milwaukee, USA, haber donado los DNAs de M. tuberculosis H37Rv (ATCC No 27294), M. tuberculosis var. bovis BCG Pasteur (ATCC No 27291), $M$. smegmatis (ATCC $\mathrm{N}^{\circ}$ 700084) y $M$. marinum (ATCC $\mathrm{N}^{\circ}$ 15.069). Al Dr. Guillermo Figueroa, del Instituto Nacional de Tecnología de los Alimentos (INTA) de la Universidad de Chile, Santiago, Chile, la donación del DNA de Helicobacter pylori TN5. Al Dr. Guido C. Mora de la Universidad Andrés Bello de Santiago de Chile, y a la Dra. Mercedes Zaldívar, de la Universidad San Sebastián de Santiago de Chile, por la lectura crítica del manuscrito. A los miembros del Programa de Control de la Tuberculosis de la VII Región del Bío-Bío, Chile, por la asistencia técnico-clínica y a Gendarmería de Chile por la colaboración brindada en el Hospital del Centro de Reclusión Penitenciario "El Manzano" de Concepción, Chile. Al Dr. Hugo Peña, Jefe del Centro de Biotecnología de la Universidad Federico Santa María de Valparaíso, Chile, por permitirnos el acceso a un equipo de PCR de tiempo real, así como a Ingrid Ramírez, por su asistencia técnica en éste.

\section{Bibliografía}

1.- KARAKOUSIS P, YOSHIMATSU T, LAMICHHANE G, WOOLWINE S, NUERMBERGER E, GROSSET J, et al. Dormancy phenotype displayed by extracellular Mycobacterium tuberculosis within artificial granulomas in mice. J Exp Med 2004; 200: 647-57.

2.- GLICKMAN M, JACOBS Jr W. Microbial pathogenesis of Mycobacterium tuberculosis: Dawn of a discipline. Cell 2001; 104: 477-85.

3.- Global tuberculosis control. Bulletin WHO. Geneva, 
Switzerland. http://www.who.int/tdr/svc/diseases/tuberculosis.

4.- Global tuberculosis control. Bulletin WHO. Geneva, Switzerland. http://www.who.int/tb/publications/global_report/2009.

5.- BORGDORFF M W. Annual risk of tuberculosis infection time for an update? Bulletin WHO 2002; 80: 501-2.

6.- COLE S, BROSCH R, PARKHILL J, GARNIER T, CHURCHER C, HARRIS D, et al. Deciphering the biology of Mycobacterium tuberculosis from the complete genome sequence. Nature 1998; 393: 537-44.

7.- MDIVANI N, LI H, AKHALAIA M, GEGIA M, GOGINASHVILI L, KERNODLE D, et al. Monitoring Therapeutic Efficacy by Real-Time Mycobacterium tuberculosis mRNA Detection in Sputum. Clin Chem 2009; 55: 1694-700.

8.- TIMM J, POST F, BEKKER L, WALTHER G, WAINWRIGHT H, MANGANELLI R, et al. Differential expression of iron-, carbon-, and oxygen-responsive mycobacterial genes in the lungs of chronically infected mice and tuberculosis patients. Proc Natl Acad Sci USA 2003; 100: 14321-6.

9.- ZAHRT T, DERETIC V. Mycobacterium tuberculosis signal transduction system required for persistent infections. Proc Natl Acad Sci USA 2001; 98: 12706-11.

10.- SANKAR S, KUPPANAN S, BALAKRISHNAN B, NANDAGOPAL B. Analysis of sequence diversity among IS6110 sequence of Mycobacterium tuberculosis: possible implications for PCR based detection. Bioinformation 2011; 6: 283-5.

11.- TALAAT A, LYONS R, HOWARD S, JOHNSTON $\mathrm{S}$. The temporal expression profile of Mycobacterium tuberculosis infection in mice. Proc Natl Acad Sci USA 2004; 101: 4602-7.

12.- ZAHRT T, DERETIC V. An essential two-component signal transduction system in Mycobacterium tuberculosis. J Bacteriol 2000; 182: 3832-8.

13.- ZAHRT T, WOZNIAK C, JONES D, TREVETT A. Functional analysis of the Mycobacterium tuberculosis MprAB two-component signal transduction system. Infect Immun 2003; 71:6962-70.

14.- MINISTERIO DE SALUD DE CHILE. Manual de Procedimientos Programa de Tuberculosis. http://www. redsalud.gov.cl/archivos/TUBERCULOSIS.pdf.

15.- LEÓN G, MAULÉN N, FIGUEROA J, VILLANUEVA J, RODRÍGUEZ, C, VERA M, et al. A PCR-based assay for the identification of the fish pathogen Renibacterium salmoninarum. FEMS Microbiol Lett 1994; 15, 115: 131-6.

16.- WALSH P, METZGER, D, HIGUCHI R. Chelex 100 as a medium for simple extraction of DNA for PCR-based typing from forensic material. Biotechniques 1991; 10: 506-13.

17.- HEGINBOTHOM M, MAGEE J, FLANAGAN P. Evaluation of the Idaho Technology LightCycler ${ }^{\mathrm{TM}}$ PCR for the direct detection of Mycobacterium tuberculosis in respiratory specimens. Int J Tuberc Lung Dis 2003; 7: 78-83.

18.- KUMAR M, KHAN F, SHARMA S, KUMAR R, FAUJDAR J, SHARMA R, et al. Identification of $M y$ cobacterium tuberculosis genes preferentially expressed during human infection. Microb Pathog 2011; 50:31-8.

19.- SOLDINI S, PALUCCI I, ZUMBO A, SALI M, RIA F, MANGANELLI R, et al PPE_MPTR genes are differentially expressed by Mycobacterium tuberculosis in vivo. Tuberculosis (Edinb) 2011; 91: 563-8.

20.- DUTTA N, MEHRA S, DIDIER P, ROY C, DOYLE L, ALVAREZ X, et al. Genetic requirements for the survival of tubercle bacilli in primates. J Infect Dis 2010; 201: 1743-52.

21.- AZHIKINA T, SKVORTSOV T, RADAEVA T, MARDANOV A, RAVIN N, APT A, et al A new technique for obtaining whole pathogen transcriptomes from infected host tissues. Biotechniques 2010; 48: 139-44.

22.- MCEVOY C, FALMER A, GEY VAN PITTIUS N, VICTOR T, VAN HELDEN P, WARREN R. The role of IS6110 in the evolution of Mycobacterium tuberculosis. Tuberculosis 2007; 87: 393-404.

23.- BARNES P, CAVE M. Molecular epidemiology of tuberculosis. N Engl J Med 2003; 349: 1149-56.

24.- WU S, HOWARD S, LAKEY D, KIPNIS A, SAMTEN $\mathrm{B}$, SAFI $\mathrm{H}$, et al. The principal sigma factor sigA mediates enhanced growth of Mycobacterium tuberculosis in vivo. Mol Microbiol 2004; 51: 1551-62.

25.- BETTS J, LUKEY P, ROBB L, MCADAM R, DUNCAN K. Evaluation of a nutrient starvation model of Mycobacterium tuberculosis persistence by gene and protein expression profiling. Mol Microbiol 2002; 43: 717-31.

26.- HESSNER M, SINGH V, WANG X, KHAN S, TSCHANNEN M, ZAHRT T. Utilization of a labeled tracking oligonucleotide for visualization and quality control of spotted 70-mer arrays. BMC Genomics 2004; 5: 12 .

27.- HE H, HOVEY R, KANE J, SINGH V, ZAHRT T. $\mathrm{MprAB}$ is a stress-responsive two-component system that directly regulates expression of sigma factors SigB and SigE in Mycobacterium tuberculosis. J Bacteriol 2006; 188: 2134-43.

28.- LI L, MAHAN C, PALACI M, HORTER L, LOEFFELHOLZ L, JOHNSON J, et al. Sputum Mycobacterium tuberculosis mRNA as a marker of bacteriologic clearance in response to antituberculosis therapy. J Clin Microbiol 2010; 48: 46-51.

Correspondencia a:

Dra. Nancy P. Maulén L.

Profesor Asistente, Facultad de Medicina y Biociencias.

Campus Los Leones. Universidad San Sebastián.

Santiago. Chile.

Tel.: (56)-2-29154739.

E-mail: n.maulen@gmail.com nancy.maulen@uss.cl 